\title{
ON MORE ACCURATE REVERSE MULTIDIMENSIONAL HALF-DISCRETE HILBERT-TYPE INEQUALITIES
}

\author{
BICHENG YANG
}

Abstract. By using the methods of weight functions and Hermite-Hadamard's inequality, two kinds of more accurate equivalent reverse multidimensional half-discrete Hilbert-type inequalities with the kernel of hyperbolic cotangent function are given. The constant factor related to the Riemann zeta function is proved to be the best possible.

Mathematics subject classification (2010): 26D15, 47A07, 37A10.

Keywords and phrases: Multidimensional half-discrete Hilbert-type inequality, weight function, Riemann zeta function, equivalent form, reverse.

\section{REFERENCES}

[1] G. H. Hardy, J. E. Littlewood, G. Pólya, Inequalities, Cambridge University Press, Cambridge, 1934.

[2] D. S. Mitrinović, J. E. PeČArić, A. M. Fink, Inequalities involving functions and their integrals and derivatives, Kluwer Acaremic Publishers, Boston, 1991.

[3] B. C. Yang, Hilbert-type integral inequalities, Bentham Science Publishers Ltd., The United Arab Emirates, 2009.

[4] B. C. YAng, Discrete Hilbert-type inequalities, Bentham Science Publishers Ltd., The United Arab Emirates, 2011.

[5] B. C. YANG, The norm of operator and Hilbert-type inequalities, Science Press, Beijing, China, 2009.

[6] B. C. YANG, On Hilbert's integral inequality, Journal of Mathematical Analysis and Applications, 220 (1998), 778-785.

[7] B. C. Yang, I. Brnetić, M. Krnić, J. PeČArić, Generalization of Hilbert and Hardy-Hilbert integral inequalities, Math. Ineq. and Appl., 8, 2 (2005), 259-272.

[8] M. KRnić, J. PeČArić, Hilbert's inequalities and their reverses, Publ. Math. Debrecen, 67, 3-4 (2005), 315-331.

[9] Y. Hong, On Hardy-Hilbert integral inequalities with some parameters, J. Ineq. in Pure \& Applied Math., 6, 4 (2005) Art. 92, 1-10.

[10] B. C. YANG, M. KRnić, On the norm of a mult-dimensional Hilbert-type operator, Sarajevo Journal of Mathematics, 7, 20 (2011), 223-243.

[11] M. Krnić, J. E. PeČArić, P. Vuković, On some higher-dimensional Hilbert's and Hardy-Hilbert's type integral inequalities with parameters, Math. Inequal. Appl., 11 (2008), 701-716.

[12] M. Krnić, P. Vuković, On a multidimensional version of the Hilbert-type inequality, Analysis Mathematica, 38 (2012), 291-303.

[13] M. Th. Rassias, B. C. YANG, A multidimensional half-discrete Hilbert-type inequality and the Riemann zeta function, Applied Mathematics and Computation, 225 (2013), 263-277.

[14] B. C. YANG, Q. ChEN, A multidimensional discrete Hilbert-type inequality, Journal of Mathematical Inequalities, 8, 2 (2014), 267-277.

[15] B. C. YANG, A mixed Hilbert-type inequality with a best constant factor, International Journal of Pure and Applied Mathematcs, 20, 3 (2005), 319-328.

[16] B. C. YANG, A half-discrete Hilbert-type inequality, Journal of Guangdong University of Education, 31, 3 (2011), 1-7. 
[17] W. Y. ZHONG, A mixed Hilbert-type inequality and its equivalent forms, Journal of Guangdong University of Education, 31, 5 (2011), 18-22.

[18] M. TH. RASSiAs, B. C. YANG, On half-discrete Hilbert's inequality, Applied Mathematics and Computation, 220 (2013), 75-93.

[19] W. Y. ZhONG, B. C. YANG, On multiple Hardy-Hilbert's integral inequality with kernel, Journal of Inequalities and Applications, Vol. 2007, Art.ID 27962, 17 pages, doi: 10.1155/ 2007/27.

[20] B. C. YANG, Q. CHEN, A half-discrete Hilbert-type inequality with a homogeneous kernel and an extension, Journal of Inequalities and Applications, 124 (2011), doi:10.1186/1029-242X-2011-124.

[21] B. C. YANG, A half-discrete Hilbert-type inequality with a non-homogeneous kernel and two variables, Mediterranean Journal of Methematics, 10 (2013), 677-692.

[22] B. C. YANG, Hilbert-type integral operators: norms and inequalities (In Chapter 42 of "Nonlinear analysis, stability, approximation, and inequalities" (P. M. Paralos et al.)), Springer, New York, 771$859,2012$.

[23] J. C. KuAng, Applied inequalities, Shangdong Science Technic Press, Jinan, China, 2004.

[24] Y. Q. ZHONG, On complex functions, Higher Education Press, Beijing, China, 2004.

[25] J. C. KUANG, Introduction to real analysis, Hunan Education Press, Chansha, China, 1996. 